DOI https://doi.org/10.18551/rjoas.2018-07.01

\title{
FREE TRADE AREA AGREEMENT OF ASEAN ECONOMICS AND RICE TRADING POLICY IN INDONESIA
}

\author{
Wisnujati Nugrahini Susantinah* \\ Student of University of Brawijaya, Malang \& Lecturer of Wijaya Kusuma University, \\ Indonesia
}

\author{
Nuhfil Hanani, Setiawan Budi, Syafrial, Lecturers \\ University of Brawijaya, Malang, Indonesia \\ *E-mail: wisnujatinugrahini@gmail.com
}

\begin{abstract}
Indonesia as a country with the highest consumption of rice in the world (Ministry of Agriculture, 2012) but has not been able to meet domestic production, ironically reduced agricultural land is converted to non-agricultural land, poor inputs, unsustainable credit granting, low technology leads to low production, so the policy alternatives are importing, on the other hand, Indonesia is a member of the ASEAN economic community (MEA) in the hope of being able to meet the rice production because the ASEAN MEA commitment becomes a production base and can compete with other countries in the world by launching single market. To anticipate the existence of MEA, and the anticipation of the import of rice of world rice exporter countries, it is necessary to analyze the impact of MEA existence, and anticipation of rice imports of world rice exporter countries by using policy simulation. The results showed that rice crops tendency in Indonesia from year to year decreased, so that rice production decreased, but if Indonesia reduces rice imports it can increase productivity so that the price decreases and demand for price increases. As a result of the agreement of MEA Indonesia imported to Thailand and Vietnam, but Indonesia prefers import from Vietnam country as import country because Vietnamese rice price is cheaper. The removal of import restrictions from Vietnam and Thailand has lowered rice imports from Thailand and increased imports from Vietnam. The policy of decreasing imports from India and China resulted in the decline of rice from both countries and Thailand but increased rice imports from Vietnam.
\end{abstract}

\section{KEY WORDS}

ASEAN Economic Community, import, simulation, exporter, rice.

The world's rice market is the thin market and residual market, meaning that the rice traded on the world market is very small and the rest of the exporter's country's inventory) so that the world rice market is uncertain,

Paddy production in Indonesia is cultivated on a small scale because rice farms in Indonesia are only available at 13.76 million hectares, with a total of 26.13 million farm households to feed the entire population of Indonesia. In addition, rice production in Indonesia of 5.01 tons per hectare is actually still low, although higher than Thailand (4.5 tons) and Vietnam (3.7 tons), Indonesia faces supply-side problems, meaning that rice production in Indonesia is relatively small compared to the consumption of its population, consumption of Indonesia's rice is highest compared with the population of other countries in the world. therefore the country has an alternative policy of import from other countries both from ASEAN and exporting countries of the world

AEC is the economic integration as planned in ASEAN Vision 2020 (Wangke, 2014: 6) ASEAN Vision 2020, is an effort to create a stable, prosperous and highly competitive ASEAN economy. goods, services, investments, economic development of skilled labor and poverty reduction and socio-economic disparities by 2020 "(Wangke, 2014: 6). MEA is a free trade area (FTA) which is expected to become a production base and become a single 
market, of course, this agreement will have consequences for Indonesia because Indonesia's capability is not the same as other ASEAN countries such as cultivated land, inputs, the technology used and the price set at harvest time.

With the MEA as a production base, is expected to meet the demand of the ASEAN community at a relatively cheap price.

Research purposes:

- To analyze the impact of the ASEAN Economic Community (MEA) Agreement;

- To analyze the impact of decreasing rice import from the world rice exporter countries.

\section{METHODS OF RESEARCH}

Kinds and Data Sources. The data used in this study is secondary data based on time series (time series), from 1980 to 2013 period. While the data collected from various sources are: Food and Agriculture Organization (FAO); Central Bureau of Statistics (BPS); Bank Indonesia; Ministry of Agriculture; Public company BULOG; International Food Policy Research Institute (IFPRI); Commodity and Trade (Comtrade).

The data used in this study are secondary time series data from 1980-2013. Secondary data were obtained from several sources such as Food and Agriculture Organization (FAO), UN Data, Central Bureau of Statistics (BPS), Bank Indonesia, Commodity and Trade (Comtrade), Ministry of Agriculture, and Directorate General of Food Crops.

The next step is to perform tabulation of data, analysis of several stages including model specification, model identification, model estimation, model validation from an econometric model, as for data forecasting using data from 2013 until 2033, and simulation with forwarding simulation type (ex-ante simulation). In this simulation, two simulations have simulated the performance of Indonesian rice, simulation of AEC impact and simulation of world rice trade policy.

The econometric model of rice commodity in this study is organized into 8 equations, consisting of 7 structural equations and 1 identity equation. The structural equation is a representation of the endogenous variables of exogenous variables that operationally rely on the sign and the magnitude of parameter estimation values according to the theory. A Flow of variable linkage can be seen in Figure 1.

In this study, the econometric model is divided into several blocks, among others: 1. Domestic rice market block, 2. ASEAN market block or AEC, and 3. World market block.

Block Domestic Rice Market. It consists of the identity equation of QIN, and the structural equation of APB, RB, DKPITA.

Rice production is a certain amount of rice obtained from the multiplication of Indonesian rice harvest area with maternal rice productivity mathematically the identity equation of Indonesian rice production as follows:

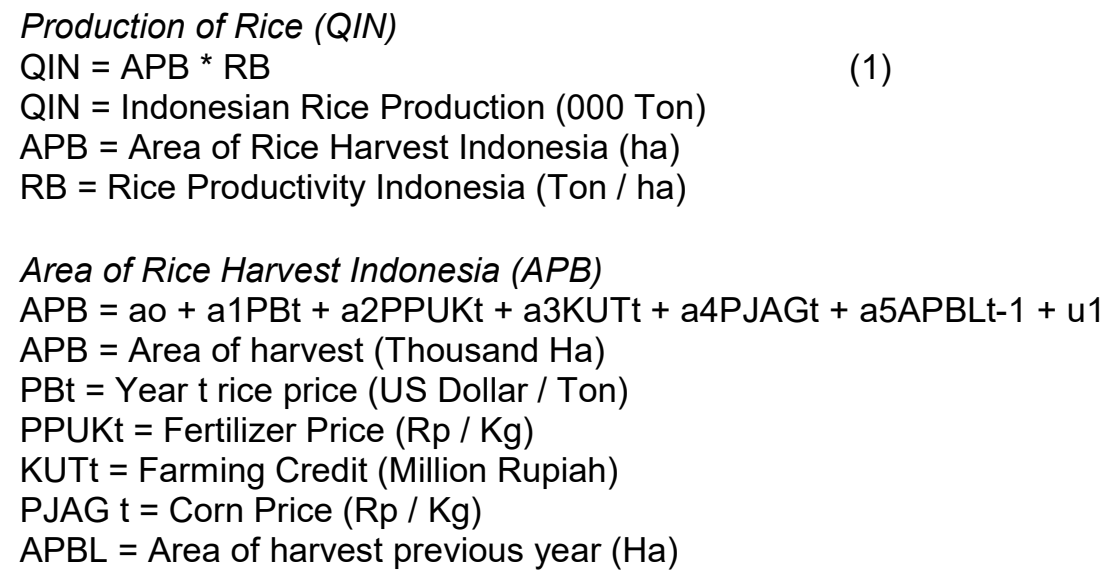


The Productivity of rice in Indonesia influenced by rice price (PB), harvested area (APB), the price of fertilizer (PPUK) and rice productivity of Indonesia the previous year $(\mathrm{RBL})$, is formulated as follows:

The Productivity of Rice Indonesia (RB)

$\mathrm{RB}=\mathrm{b} 0+\mathrm{b} 1 \mathrm{~PB}+\mathrm{b} 2 \mathrm{APB}+\mathrm{b} 3 \mathrm{PPUK}+\mathrm{b} 4 \mathrm{RBLt}-1+\mathrm{u} 2$

$\mathrm{RB}=$ Productivity In Year $\mathrm{t}($ Ton $/ \mathrm{Ha})$

$\mathrm{PB}=$ Indonesian rice price (USD / Ton)

PPUK = Price Fertilizer $(\mathrm{Kg} / \mathrm{Rp})$

RBt-1 $=$ Productivity Previous Year

Rice Demand Per Capita (DKPITA)

DKPITA $=\mathrm{c} 0+\mathrm{c} 1 \mathrm{PBt}+\mathrm{c} 2 \mathrm{Int}+\mathrm{c} 3 \mathrm{DKPITALt}-1+\mathrm{u} 3$

DKPITA = Demand for rice per Capita (Ton / person)

$\mathrm{PB}=$ Price of Rice (USD / Ton)

DKPITAL = Rice demand of previous year (Ton / person)

\section{ASEAN Market Block:}

Import of Indonesian rice from Thailand (MTH)

MTH = d0 + d1QINTH + d2PTH + d3RTHH + d4ERTH + d5MTHLt-1 + u4

$\mathrm{MTH}=$ Import Rice from Thailand country (000 ton)

QINTH = Indonesian Rice Production (000 ton)

PTH = Rice Price from Thailand (USD / Ton)

ERTH = Thailand Exchange Rate (Bath / USD)

$\mathrm{PW}=$ World price of rice (USD / Ton)

$\mathrm{MTHL}=$ Imported rice from Thailand last year (000 Ton)

Import of Indonesian Rice From Vietnam (MV)

$\mathrm{MV}=\mathrm{e} 0$ + e1QINV + e2PVT + e3PW + e4RVT + e5ERVT + e6MVLt-1 + u5

QINV = Indonesian Rice Production (000 Ton)

PVT = Rice Price from Vietnam (USD / Ton)

ERVT = Vietnamese Exchange Rate (Dong / USD)

$\mathrm{PW}=$ World price of rice (USD / Ton)

RVT = Rice Trade Rice Vietnam

$M V L=$ Import of rice from Vietnam Country of previous year (000 Ton)

World Market Block. Based on Who country.co's information on the world's top ten rice exporting countries, it states that India, Pakistan is an exporter with exports of Pakistan of 3800,000 metric tons, China of 600 metric tons and India of 2200 metric tons.

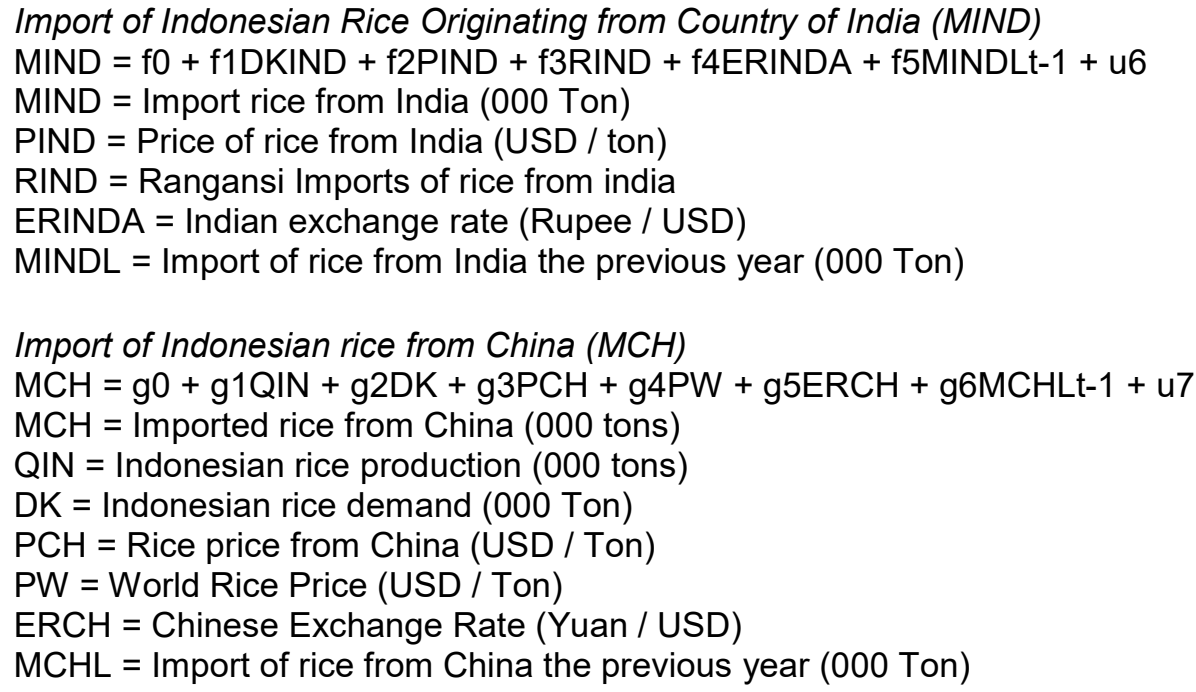




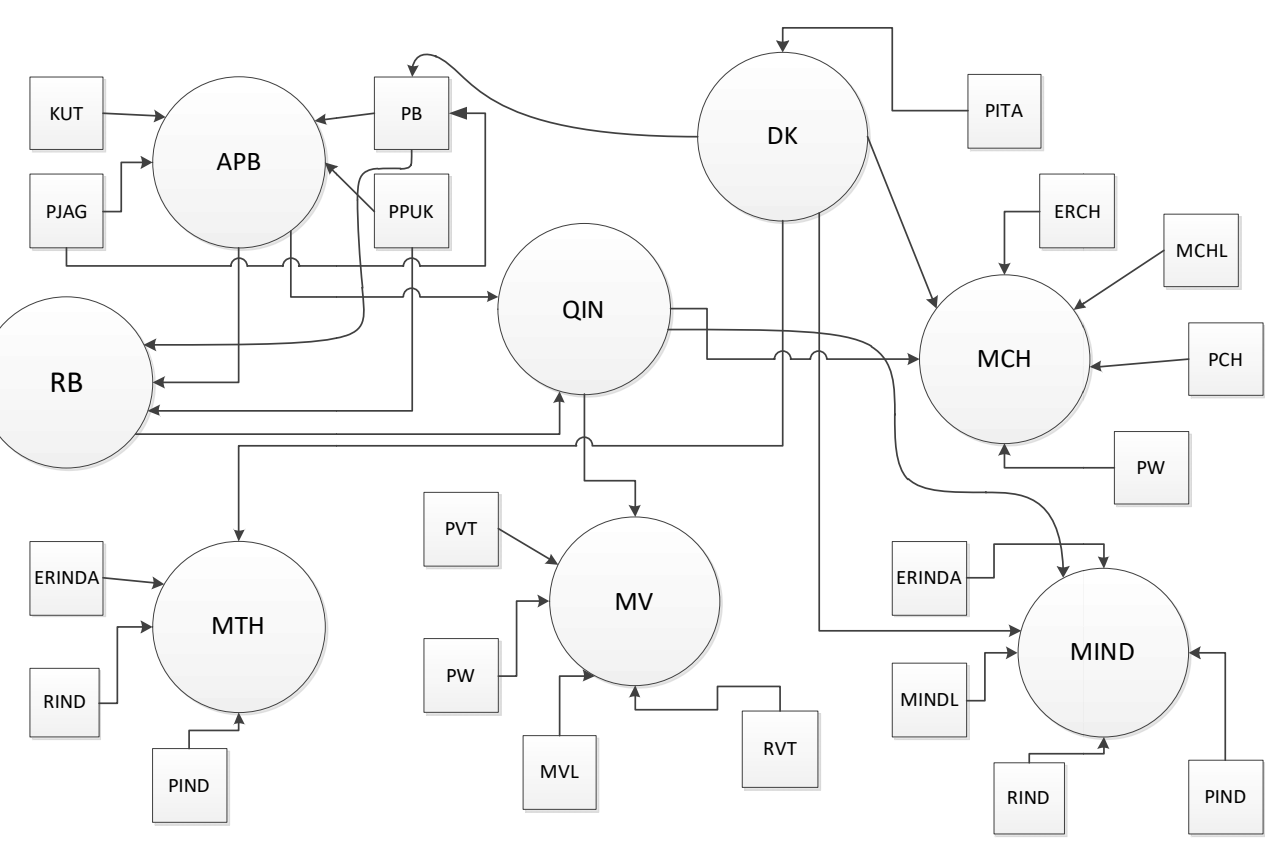

Figure 1 - Indonesian Rice Performance Study Model

\section{RESULTS AND DISCUSSION}

From the FAO data of 2016, it shows that Indonesia's rice price is ranked highest, or the most expensive compared to the price of rice from India and China.

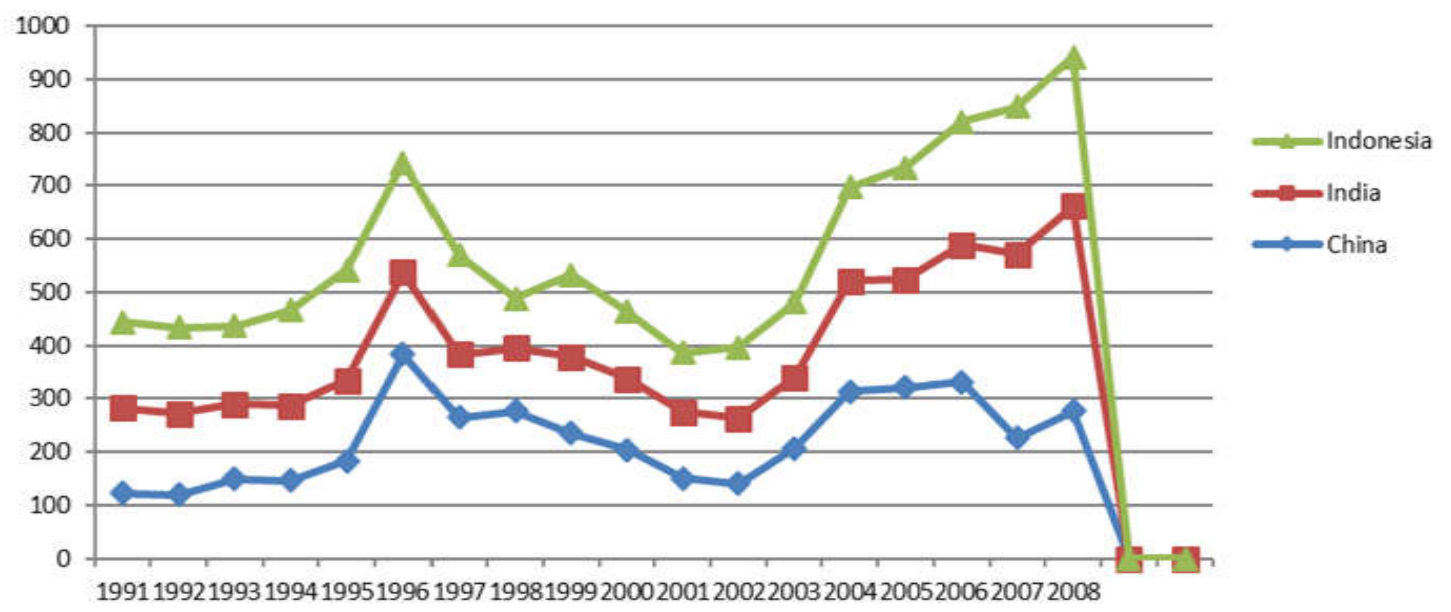

Figure 2 - Rice Price in to ASIA Countries (Source: Secondary Data, FAO 2016)

Figure 2 shows that Indonesia is still not able to compete with other ASIA countries, this is because Indonesia has not been able to determine the cheap price. This is because the cost of rice production is highest among exporting countries such as India and China. Production costs include agricultural land, agricultural technology means of production. So there needs to be more technology use in every line like start planting, weeding, and harvesting. Fertilizer subsidies, the provision of credit aid to farmers should be more appropriately calculated because so far the aid is unsustainable and sometimes subsidized fertilizers cannot be found in certain areas.

The determination of price policy will minimize the risk of rice farming because there is a guarantee of the falling of the selling price of grain under the cost of production. Falling selling prices usually occur during harvest time, in 2004 the determination of rice price in Indonesia based on production cost does not refer to international rice price (Sawit, 2011). 


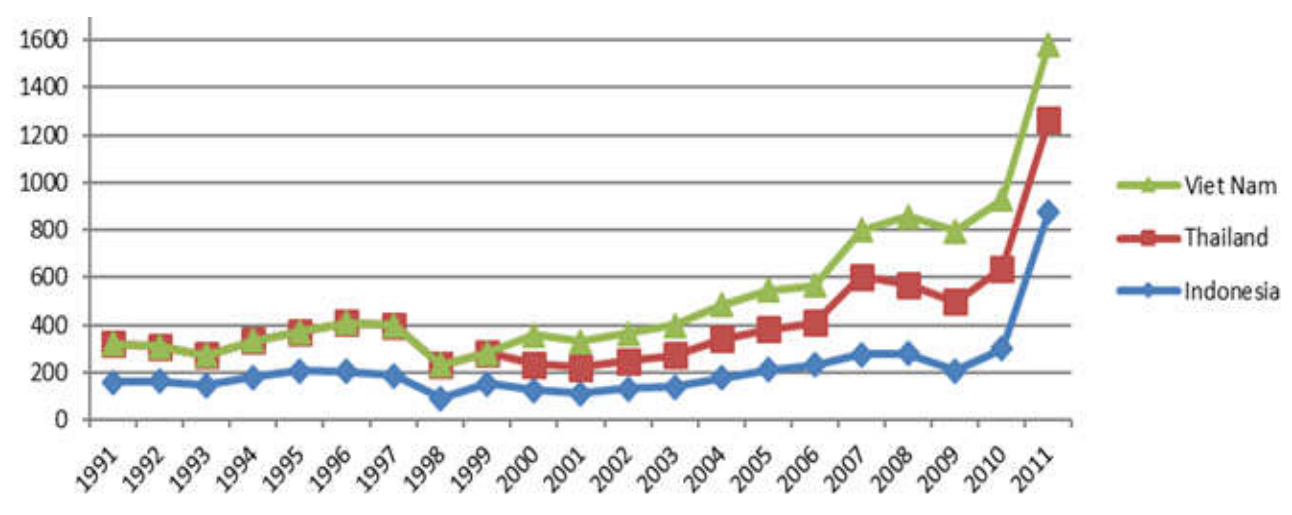

Figure 3 - Rice Production Costs (Source: Secondary Data, FAO 2016)

But in the ASEAN region, Indonesia has the cheapest price of rice, but the price at the producer level, the price of Indonesian rice is cheaper than the price of Vietnam and Thailand from 1991 to 2011, meaning that Indonesia is able to compete with the countries in the ASEAN region.

Policy Simulation on Elimination Restriction of import from Vietnam. Blueprint MEA is the base of rice and single market, import restriction is abolished, Indonesian rice imports come from ASEAN countries such as Thailand and Vietnam, the two countries are more developed countries in applying agricultural technology and able to streamline production costs, the data show that the price at the level of Indonesian rice producers is cheaper than Vietnam and Thailand but in the world rice trade both countries are able to compete with other countries in the world, it is necessary to examine the impact of decreasing rice imports from the two ASEAN countries, for clarity can be seen in the following table.

Table 1 - Policy Simulation on Elimination Restriction of import from Vietnam 1\%

\begin{tabular}{|c|c|c|c|c|c|c|}
\hline \multirow{2}{*}{ No } & \multirow{2}{*}{ Variabel } & \multicolumn{2}{|c|}{ Value } & \multicolumn{2}{|c|}{ Change } & \multirow{2}{*}{ Variable Discription } \\
\cline { 3 - 5 } & & Basic & SIM I & Unit & $(\%)$ & Area of Harvest Land (Ha) \\
\hline 1 & APB & 11692,3 & 11278 & $-414,3$ & 3,67352 & Productivity (Ton / Hectare) \\
2 & RB & 4,3528 & 4,397 & 0,0442 & 1,00523 & Production (Ton) \\
3 & QIN & 51430,5 & 50048,4 & $-1382,1$ & 2,76153 & Rice Price (US Dollar / Ton) \\
4 & PB & 16,3201 & 16,1694 & $-0,1507$ & 0,93201 & Indonesian Rice Demand (Ton) \\
5 & DK & 33951,1 & 33963,4 & 12,3 & 0,03621 & Rice Demand Per Capita (Ton) \\
6 & DKPITA & 0,00017 & 0,00017 & 0 & 0 & Import From Thailand (Ton) \\
7 & MTH & 6219,1 & 6209,9 & $-9,2$ & 0,14815 & Import From Vietnam (Ton) \\
8 & MV & 3288.8 & 3336.2 & 47.4 & 1.42 & Import From China (Ton) \\
9 & MCH & 1699.2 & 1964.8 & 265.6 & 56.76 & Import From India (Ton) \\
10 & MIND & 2860.6 & 2921.5 & 60.9 & 2.09 & \multicolumn{2}{|c|}{ ITon } \\
\hline
\end{tabular}

The policy simulation results show that if rice imports from Vietnam and Thailand are reduced by 1 percent, then rice productivity will increase by 0.44 or 1 percent, indicating that if Indonesia reduces imports from Thailand and Vietnam then Indonesia will be able to increase productivity rice in Indonesia, rice productivity is supported by fertilizer price (PPUK), rice price (PB) and rice harvest area (APB). Indonesia's rice producers are still dominated by Java Island, around 56 percent of which are produced by Sumatra Island $(22 \%)$, Sulawesi $(10 \%)$, Kalimantan $(5 \%)$ and other islands $(7 \%)$, from simulation results this policy requires the effort to print new rice fields both on Java island and outside Java Island. The existence of paddy fields is not only able to support food security, but also to maintain the production system, to maintain the environment and the inheritance of cultural values. (Efendi Pasandaran, 2006)

In Indonesia, there is a decrease in rice harvest utilization, but also land conversion in watersheds, whereas the conversion of land around the watershed will disrupt the hydrological balance that will affect water availability throughout the year. Conversion of paddy fields occurs due to the scarcity of land and water resources, the dynamics of development and the increase of population. 
In fact, the problem of resource scarcity has long existed, marked by the limit to grow by the Club of Rome (Meadow 1972), and the signal of a green revolution for food fulfillment in 1960, meaning that the government has seen the phenomenon of rice scarcity in Indonesia and power in general world.

Watershed (DAS) is very important because it will create a system of irrigated rice fields, multifunctional systems, namely the function of the park is to support food production, land, water, cultivation, and the existence of community institutions, the second function is the function of biophysical conservation and maintenance irrigation and paddy field maintenance, if irrigation and rice fields are maintained then the function of conservation will run well, the third function is the function of cultural inheritance, the function of cultural inheritance is to inherit the culture of mutual assistance to the grandchildren so as to emerging social capital and local wisdom, the above description then Indonesia needs to reduce rice imports from Vietnam and Thailand, and increase rice productivity in Indonesia. Indonesia's rice imports increased from Vietnam to 1.42 percent.

With the removal of rice import restrictions from Vietnam, Indonesia reduced imports from Thailand but instead increased imports from the world, imports to India increased to 2.09 percent but imports from China increased to 56.76 percent.

To strengthen the analysis, it is necessary to predict the import of Indonesian rice from Vietnam and Thailand. Data from FAO Import Indonesia rice is mostly from two countries in ASEAN, namely Vietnam and Thailand. From 1980 to 1988 imports from both countries were relatively similar in quantity, but in 1989 Indonesia imported more from Vietnam, this can be seen in the following graph.

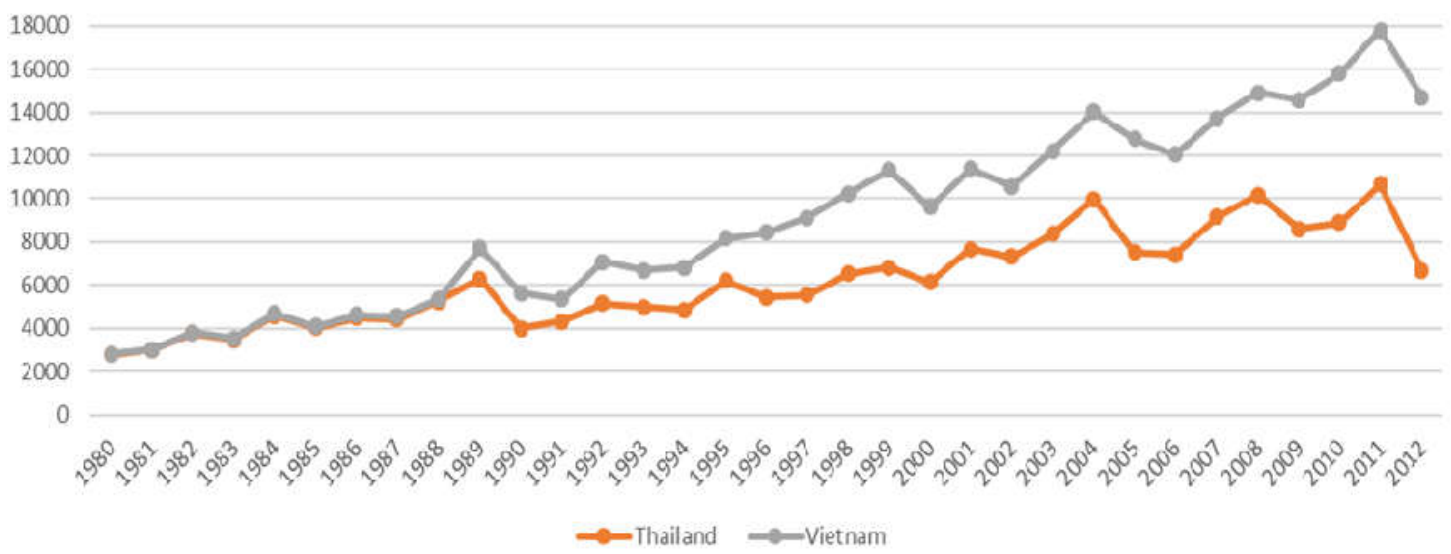

Figure 4 - Rice Import in Indonesia (Source: FAO)

In the simulation of policy resulted from the impact of rice import decline from Thailand and Vietnam, Data from FAO Import of Indonesian rice came mostly from two countries in ASEAN, namely Vietnam and Thailand. From 1980 to 1988 imports from both countries were relatively the same in quantity, but in 1989 Indonesia imported more from Vietnam.

Indonesia imports more rice from Vietnam because Vietnam's rice price is cheaper than Thailand, but the world's rice market is a thin market, as stated by (Sawit, 2008, Tabor et al 2002) residual market so that there must be serious efforts from the Indonesian state to strengthen national food security.

Simulation of Policy Restriction of import from Thailand. The import of Indonesian rice comes from ASEAN countries, namely from Thailand and Vietnam, the two countries are more advanced countries in applying agricultural technology and are able to streamline production costs, the data shows that the price at the level of Indonesian rice producers is cheaper compared to Vietnam and Thailand but in the world rice trade the two countries are able to compete with other countries in the world, it is necessary to examine the impact of the decrease of rice imports from the two ASEAN countries, for clarity can be seen in table 2 below. 
Table 2 - Policy Simulation on Elimination Restriction of import from Thailand 1\%

\begin{tabular}{|c|c|c|c|c|c|c|}
\hline \multirow{2}{*}{ No } & \multirow{2}{*}{ Variable } & \multicolumn{2}{|c|}{ Value } & \multicolumn{2}{|c|}{ Change } & \multirow{2}{*}{ Variable Discreption } \\
\cline { 3 - 6 } & & Basic & SIM I & Unit & $(\%)$ & Area of Harvest Land (Ha) \\
\hline 1 & APB & 11692,3 & 11278 & $-414,3$ & $-3,67352$ & Productivity (Ton / Hectare) \\
2 & RB & 4,3528 & 4,397 & 0,0442 & 1,00523 & Production (Ton) \\
3 & QIN & 51430,5 & 50048,4 & $-1382,1$ & $-2,76153$ & Rice Price (US Dollar / Ton) \\
4 & PB & 16,3201 & 16,1694 & $-0,1507$ & $-0,93201$ & Indonesian Rice Demand (Ton) \\
5 & DK & 33951,1 & 33963,4 & 12,3 & 0,03621 & Rice Demand Per Capita (Ton) \\
6 & DKPITA & 0,00017 & 0,00017 & 0 & 0 & Import From Thailand (Ton) \\
7 & MTH & 6219,1 & 6209,9 & $-9,2$ & $-0,14815$ & Import From Vietnam (Ton) \\
8 & MV & 3314.2 & 3336.2 & 22 & 0,66 & Import From China (Ton) \\
9 & MCH & 1699.2 & 1964.8 & 265.6 & 56.76 & Import From India (Ton) \\
10 & MIND & 2860.6 & 2921.5 & 61 & 2.09 & \\
\hline
\end{tabular}

The simulation of the policy of abolishing import restriction from Thailand indicates that the area of rice harvest still decreased by 414.3 ha or -3.67352 , but productivity increased, because the decreasing of harvested area will decrease production, but the price of rice also decreased, and demand rice increased, the impact of removing import restrictions from Thailand turned imports from Thailand down 0.15 percent, and imports from China rose to 56.76 percent. while imports rose from Vietnam and India.

Simulation of Price Policy of Indonesia is equal to Vietnam Price. Indonesia's rice imports more than Vietnam, because the price of cheap rice compared with other neighboring countries namely Thailand, another thing is the distance of the country of Vietnam is not too far with the state of Indonesia.

With the agreement of the ASEAN Economic Community where there is a single price then of course. the price of Indonesian rice should be equal to the price of Vietnamese rice. In this study simulated the policy if the price of Indonesian rice (PB) equal to the price of Vietnamese rice, the result of policy simulation as in table 3 below.

Table 3 - Price Policy Simulation of Indonesia equal to Vietnam Price

\begin{tabular}{|c|c|c|c|c|c|c|}
\hline \multirow{2}{*}{ No } & \multirow{2}{*}{ Variable } & \multicolumn{2}{|c|}{ Value } & \multicolumn{2}{|c|}{ Change } & \multirow{2}{*}{ Variable Discription } \\
\hline & & Basic & SIM 2 & Unit & $(\%)$ & \\
\hline 1 & APB & 11692,3 & 11278 & $-414,3$ & $-3,67352$ & Area of Harvest Land $(\mathrm{Ha})$ \\
\hline 2 & $\mathrm{RB}$ & 4,3528 & 4,397 & 0,0442 & 1,00523 & Productivity (Ton / Hectare) \\
\hline 3 & QIN & 51430,5 & 50048,4 & $-1382,1$ & $-2,76153$ & Production (Ton) \\
\hline 4 & PB & 16,3201 & 295.5 & $-162,9$ & $-55,13$ & Rice Price (US Dollar / Ton) \\
\hline 5 & DK & 33951,1 & 33963,4 & 12,3 & 0,03621 & Indonesian Rice Demand (Ton) \\
\hline 6 & DKPITA & 0,00017 & 0,00017 & $\overrightarrow{0}$ & 0 & Rice Demand Per Capita (Ton) \\
\hline 7 & MTH & 6219,1 & 6209,9 & $-9,2$ & $-0,14815$ & Import From Thailand (Ton) \\
\hline 8 & MV & 3314.2 & 3336.2 & 22 & 0,66 & Import From Vietnam (Ton) \\
\hline 9 & $\mathrm{MCH}$ & 1699.2 & 1964.8 & 265,6 & 13.51 & Import From China (Ton) \\
\hline 10 & MIND & 2860.6 & 2921.5 & 61 & 2.09 & Import From India (Ton) \\
\hline
\end{tabular}

The facts of this policy simulation are that rice production has declined due to decreased agricultural land, which is 1,328 or 2.76 percent, it is strongly affirmed that agricultural land is very influential on production, but with increasing productivity and decreasing import price of rice has decreased and demand rice increased.

In ASEAN trade, imported rice from Vietnam has increased, imports from Thailand have decreased, import decline from Thailand has made Indonesia increase imports from other countries, namely India and China, from China has increased up to 13.51 percent and increased import from India.

Simulation of Decreasing Policy of Import of Rice from China and India 1\%. With the existence of the ASEAN Economic Community (MEA) is expected to be able to meet the needs of Indonesian production and imports within the ASEAN countries, it is necessary to simulate the policy of Decrease Import Rice Indonesia From China, and India 1 percent, while the results can be seen in table 4 below. 
Table 4 - Policy Simulation of Decreasing Rice Import from China and India

\begin{tabular}{|c|c|c|c|c|c|c|}
\hline \multirow{2}{*}{ No } & \multirow{2}{*}{ Variable } & \multicolumn{2}{|c|}{ Value } & \multicolumn{2}{|c|}{ Change } & \multirow{2}{*}{ Variable Discription } \\
\cline { 3 - 6 } & & Basic & SIM 3 & Unit & $(\%)$ & \\
\hline 1 & APB & 11692,3 & 11278 & $-414,3$ & $-3,67352$ & Area of Harvest Land (Ha) \\
2 & RB & 4,3528 & 4,397 & 0,0442 & 1,00523 & Productivity (Ton / Hectare) \\
3 & QIN & 51430,5 & 50048,4 & $-1382,1$ & $-2,76153$ & Production (Ton) \\
4 & PB & 16,3201 & 16,1694 & $-0,1507$ & $-0,93201$ & Rice Price (US Dollar / Ton) \\
5 & DK & 33951,1 & 33963,4 & 12,3 & 0,03621 & Indonesian Rice Demand (Ton) \\
6 & DKPITA & 0,00017 & 0,00017 & 0 & 0 & Rice Demand Per Capita (Ton) \\
7 & MTH & 6219,1 & 6209,9 & $-9,2$ & $-0,14815$ & Import From Thailand (Ton) \\
8 & MV & 3314.2 & 3336.2 & 22 & 0,66 & Import From Vietnam (Ton) \\
9 & MCH & 1699.2 & -3929.6 & $-2.230,4$ & -56.76 & Import From China (Ton) \\
10 & MIND & 2860.6 & -5843.0 & -2.983 & -51.05 & Import From India (Ton) \\
\hline
\end{tabular}

The decline in imports of India (MIND) and China $(\mathrm{MCH})$ by 1 percent caused a decline in the area of rice harvest (APB), ie the area of rice harvest (APB) decreased by 414.3 hectares per year or 3.67 percent, is a threat to the sustainability of food security, especially in Indonesia, because of reduced harvested land for various reasons permanently, or permanently, the converted land will not return to wetland again. The decline in rice harvesting area of 414.3 hectares indicates that the rice harvest area in Indonesia (APB) will decrease although the import of rice in the world rice exporting country decreases, but productivity increases to 0.04 , although small still indicates that if there is decrease of import from country China (MCH) and India (MIND) will be able to increase productivity, but in general the production of rice (QIN) in Indonesia has decreased by 1,382 tons per year due to the decreasing land area of 414.3 hectares, the decreasing of rice production (QIN) (PB) also declined 0.2 US dollars, although the decline is relatively small but the decline in imports from China $(\mathrm{MCH})$ and India (MIND) by 1 percent will encourage farmers to try to increase productivity (RB) and price of rice (PB) down. Although production decreased, then rice price (PB) also fell, triggering demand for rice (DK) rose to 12.3 tons, but demand per capita (DKPITA) did not change.

On the decline of Indonesian imports from China $(\mathrm{MCH})$ and India (MIND also triggered import decline from China by -56.76 , India 51.05, from Thailand at 9.2 tons or 0.1 percent, but even increased imports from the country Vietnam by 22 tons or 0.65 percent

\section{CONCLUSION}

The impact of the ASEAN Economic Community (MEA) agreement is the abolition of rice import restrictions from Thailand and Vietnam.

Elimination of import restrictions of Thailand and Vietnam have resulted in decreasing of the harvested area (APB), increasing productivity (RB), decreasing rice price (PB) and increasing demand of rice (DK).

Single price affects the same price in ASEAN, the price of Indonesian rice is equal to the price of rice in Thailand and Vietnam. Policy simulation shows imports of rice from Thailand decline but imports from China and India.

To analyze the impact of decreasing rice imports from the world rice exporting countries, the results show that imports from China succeeded in decreasing to 56,75 percent and import decline from India by 51.05 percent.

\section{REFERENCES}

1. Dominic Salvatore, 1990 Ekonomi Internasional, Edisi Ketiga, Terjemahan, Erlangga, Jakarta.

2. Husain Sawit, 2006, Indonesia Dalam Tatanan Perubahanan Perdagangan beras Dunia, Edisi No. 47/XV/Juli/2006.

3. Federation Agriculture Organization (FAO), 2014, "Rice Market Monitor", Akses 11 Oktober 2015, http://www.fao.org/3/a-i4147e.pdf 
4. Griffin RW dan MW Pustay. 2005. International Business: A managerial Perspective. Fourth edition. Pearson Education International.

5. Henderson JM dan Quant RE. 1986. Microeconomics Theory: A Mathematical Approach. Mebrow Hill International Editors. Singapore.

6. Hill, Charles WL. 2011. International Bussiness: Competing in the Global Marketplace. Eighth edition. Mc GRAW-HILL International Edition.

7. Husted, S and M. Melvin. 2010. International Economics. Eighth edition. Pearson Education, Inc.

8. Huff, Kathryn Whittaker. 2011, Easy On an ASEAN Optimal Currency Area, University of New Orleans, ProQuest Dissertations Publishing, 2011. 3504559.

9. Isabelle Tsakok, 1990, Agricultural Price Policy, A practitioner's Guide To PartialEquilibrium Analysis, Cornell University Press.

10. Jehle, GA dan PJ Reny. 2011. Advanced Microeconomic Theory. Pearson Education Limited.

11. Johnson D dan C Turner. 2003. International Bussiness: Themes and issues in the modern global economy. Routledge Taylor \& Francis Group. London and New York.

12. Jorn Doch, 2016, The ASEAN Economic Community:What Stands in the Way?, Analysis from the East-West Center No. 119 September 2015.

13. Karim Raslan (2014), Kebijakan Beras Indonesia, https://kolom.kontan.co.id/

14. Kementerian Pertanian. 2014. Rencana Strategis Kementrian Pertanian Tahun 20152019. Jakarta.

15. Koutsoyianis A. 1977. Modern Microeconomics. Halsred Press Book Waterloo.Ontario.

16. Krugman PR and M Obstfeld.2009. International economics theory and policy. 8th ed. Boston Pearson Addison-Wesley.

17. Petri, P. A., \& Plummer, M. G. (2014). ASEAN centrality and the ASEAN-US economic relationship. Policy Studies, (69), 0_1,XI,XII,XIII,XIV,1-67,69-71,73-75,77. Retrieved from

18. https://search.proquest.com/

19. (Simone, N. D. (1995). A macroeconomic perspective of AFTA's problems and prospects. Contemporary Economic Policy, 13(2), 49. Retrieved from https://search.proquest.com/

20. (Artner, A. (2017). Role of Indonesia in the Evolution of ASEAN. The Journal of East Asian Affairs, 31(1), 1-38. Retrieved from https://search.proquest.com/ 